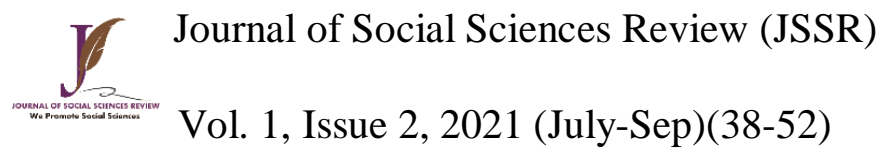

\title{
The Role of Co-curricular Activities in Leadership Skills' Development among University Students
}

\author{
Nisar Yousaf Zada ${ }^{1}$ and Dr. Alam Zeb ${ }^{2}$ \\ ${ }^{1}$ B.ED student at the Center for Education \& Staff Training University of Swat 19200, Pakistan \\ ${ }^{2}$ Center for Education and Staff Training, University of Swat 19200, Pakistan
}

\section{Author/s Note}

We (the authors) agree with the journal's open access policy, and we have no conflict of interest. This research received no specific grant from any funding agency, commercial or not-for-profit sectors. Correspondence concerning this article should be addressed to Center for Education and Staff Training, University of Swat 19200, Pakistan, Contact: $\underline{\text { alamzeb@uswat.edu.pk }}$ 


\begin{abstract}
Education aims at the balanced personality growth of individuals and offers both curricular and co-curricular activities to realize this goal. Talking about the importance of co-curricular activities in mind, the study investigated the function of co-curricular activities in leadership skills' growth among university students. The research aimed to figure out co-curricular activities among university students, examine the connection between co-curricular activities and students' leadership skills' growth, and establish techniques for co-curricular activities at the university levels. The sample of the research was all 4523 undergraduate students from 06 faculties of the University of Swat. The researchers randomly selected 60 participants for the analysis, created a questionnaire, and validated it by piloting data collection. The data were obtained with selfadministered questionnaires and evaluated with frequencies, percentages, and Chi-square test of significance. The study established the strategies of giving equal importance to co-curricular activities, motivation of students for involvement in co-curricular activities, proper scheduling for co-curricular activities, allocation of sufficient financial resources, provision of playgrounds, gymnasiums for arranging indoor, outdoor games and literary activities, and reinforcement of students' contribution in co-curricular activities with a distribution of prizes.

Keywords: co-curricular activities, development, leadership skills, role, university students
\end{abstract}


Co-curricular programs are activities that take place outside of the classroom that are managed and/or sponsored by the school or college. They include curriculum-related learning and character-building opportunities. Co-curricular programs are voluntary, do not have to be a component of the regular school or college schedule, do not include recognition, and are not evaluated. Co-curricular events are such things that take place inside or outside of the school or college grounds that are supported by the Board of Education in the formation of various topic societies, unions, and student organizations (Marsh \& Kleitman, 2002). Civic growth activities, voluntary work, recreational sports, physical development practices, cultural and aesthetic initiatives, literary and excursion programs are also examples of co-curricular activities (Mani, 2018).

Co-curricular Activities also includes student teams, athletic leagues, and cultural events societies that put on certain events. Co-curricular programs are often distinguished from formal classes, although this is not always the case. They may be ungraded, do not allow students to earn academic credit, take place outside of school or college or during regular school or college hours, and are handled by outside organisations. Co-curricular programs are intended to complement the school program by providing opportunities for hands-on learning and instilling skills that can aid in self-development. Organizing various activities or projects exposes students to the modern environment, job ethic, and genuine problems in an indirect manner. This experiences will aid in the development of a healthy attitude while also improving soft skills (Ahmad, 2013).

Co-curricular activities can often mean that extracurricular activities are a way for college students to improve their social involvement, teamwork, balanced recreation, self-discipline, and self-confidence. Co-curricular programs support students in meeting their life objectives, 
improving their decision-making power, strengthening their self-confidence, building social partnerships, developing their capacity to address obstacles successfully, developing team spirit, developing the spirit of sacrifice, and assisting them in learning the experiences of others. At higher stages of schooling, co-curricular activities may often be translated into academic marks. Despite the fact that several research have been conducted to assess the impact of co-curricular activities on all aspects of a student's development (Kumar et al., 2004; Darling et al., 2005). Leadership abilities include the ability to exercise leadership qualities as well as a range of activities for doing so. According to Yulk (2001), a leader's task is to make sure that everybody respects the goals that have been established. The emphasis of this study is on leadership skills, and it goes without saying that the success of an organisation cannot be separated from the role of leadership. Individuals who are leaders possess the necessary qualifications to advance their careers to become effective bosses in the workplace. The birth of a king is a long process. Leadership is both a science and an ability that can be learned, practiced, and improved over time by leadership learning programs such as co-curricular activities (Dhanmeher, 2014).

Co-curricular practices have been described as being very important and essential for students' holistic growth in terms of their physical, spiritual, academic, social, and emotional dimensions, according to studies. Educational programs have been classified as empowering young people to mix with adults and friends in order to set and achieve targets, productive competition, a lift from loss or rejection, and successful settlement of disputes (Caldwell \& Smith, 2005). Co-curricular events will also make it possible for students to make new friends and meet people who have similar interests and abilities. It has been discovered that students who partake in extracurricular activities have the potential to achieve individual achievement and 
career performance in the future, to integrate themselves into community, and to develop a deep understanding of the importance of commitment, hard work, integrity, and openness. Participation of co-curricular activities improves a young person's ability to avoid negative behaviors such as anti-social behaviour, opioid use, illegal intercourse, delinquency, and the consumption of alcoholic beverages (Klesse \& D'Onofrio, 2000).

Students' teamwork, goal setting, organizing, cooperation, decision-making, dispute resolution, and group tolerance are all developed through co-curricular activities, according to Klesse and D'Onofrio (2000). As a cognitive aspect, they learn from social experiences, selfesteem, self-confidence, and leadership abilities. Students were able to combine academic experience and personal activities by co-curricular activities, according to Allison (1979). Giving students the ability to participate in co-curricular activities builds their leadership skills and improves their academic performance through giving them the confidence to compete and the experience of dealing with real-life issues, especially through activities like competitiveness and real-world simulations.

The role of the chair at a higher institution in the classroom, club, or other institution is the most important element in achieving the desired outcome successfully. According to Bassoppo-Moyo (2007), leadership affirmation is very important to the program evaluation's result in order to guarantee the program's success. The key leader is responsible for providing approval for all of the college-wide changes. Many findings have suggested that a leader's status influences the effective implementation of a program evaluation's result. The duties of the chair of the program evaluation and the application of the review findings are required in order for the program to be correctly identified in order to prepare and evaluate the importance of the role of the chair (Tucker, 1993). 
The tasks of leadership, according to Sari et al., (2014), are inextricably linked to the organization's decision-making mechanism, activities, and efficiency. Sport-related activities and athletic abilities are extremely useful for improving leadership skills and preparing for adult life in community. Chelladurai (2011) explained how a coach leads in co-curricular activities based on many leadership traits, such as deciding the task and intent for which the coach organized a new way of addressing challenges and fulfilling demands in sports.

Lupu (2011) believed that in co-curricular practices, the rule of competition encourages students to cultivate healthy attitudes, have good relationships with their peers, and lead effective organizational lives. According to the respondent's input, leadership qualities can be mastered while each manager of the squad, as well as the team captain and the coaching committer, are competing against teams from other organizations.

The desire to use organizational strategies in a variety of activities, understanding of fundamental leadership theory, the capacity to coordinate campaigns, and the ability to supervise team members are also examples of communication talents at the university level. This number, on the other hand, should be consistent with applicability. Curricular activities are very important in the schooling and learning phase for learners to align and include students in terms of selfphysical, mental, and academic terms. The goal of incorporating curricular activities is to give students a more vivid, enjoyable, and positive outlook on the world and society (Hoe, 1999). An extra-curricular practice complements the class and is a subset of it. While there is a very short time frame for co-curricular activities, the majority of students are attentive to teaching tasks in the classroom. To assume a leadership position, one who can guide and counsel staff in the event that others have an impact on the success of integrity-based positions and ethical leaders to achieve the goals set, have confidence in reminding others of the decision, are wise in 
synthesizing and evaluating outcomes, and eventually have thorough knowledge of the leader (Zaid et al., 2011).

The goal of university education is to build students' leadership skills so that they can confidently access the modern world of action and effectively face social and career challenges. Participation of co-curricular programs provided by higher education agencies helps to improve these skills. Given the significance of these activities in the development of undergraduate leadership skills, the study's aim is to look into the function of co-curricular activities in the development of leadership skills among university students.

\section{Methodology}

\section{Population Sample and Sampling}

A total of 4523 undergraduate students from the University of Swat's six faculties comprised the study's community. Language and Literature, Physical and Mathematical Sciences, Management and Social Sciences, Religions and Legal Studies, Chemical Technology, and Life Sciences were the faculties in question. The researchers randomly picked 60 sixty students (30 males and 30 females) from these faculties' student bodies.

\section{Instrumentation}

The researchers themselves created a questionnaire with (15) elements. The questionnaire's items were divided into two subcategories: the first was about co-curricular activities in which students participated, and the second was about the role of co-curricular activities in the development of leadership skills among university students. Following the development of the questionnaire, it was validated with the help of experts and administered to 25 students in order to determine the questionnaire's reliability. The reliability coefficient was 0.78, which was sufficient since the questionnaire was able to provide accurate data. 


\section{Data collection and analysis}

During the data collection period, the questionnaires were distributed to a test study community of Swat University students. During the delivery of the questionnaire, the elements were demonstrated to the participants. The data are collected by the researcher himself. The inspectors visited the university's divisions on a daily basis, handing out questionnaires to anyone who responded. Both data was entered into the Statistical Package for Social Sciences (SPSS) version 16.0 program and evaluated using frequency, percentages, and the Chi-square scale.

\section{Results and Discussion}

Table 1

Co-curricular activities of students at university

\begin{tabular}{llllc}
\hline \multicolumn{1}{c}{ Co-curricular Activities } & Yes & No & $\chi^{2}$ & P \\
\hline Campaigns & $27(45)$ & $33(55)$ & 19.06 & .000 \\
Cultural Activities & $37(61.7)$ & $23(38.3)$ & 28.96 & .000 \\
Excursions & $21(35)$ & $39(65)$ & 81.66 & .000 \\
Literary Activities & $36(60)$ & $24(40)$ & 33.50 & .000 \\
Sports & $37(61.7)$ & $23(38.3)$ & 40.92 & .000 \\
\hline
\end{tabular}

Table 1 summarizes the co-curricular programs in which undergraduate students are involved. According to the table, 45 percent of students engage in projects, 61.7 percent engage in artistic events, 35 percent engage in excursions, 60 percent engage in literary activities, and 61.7 percent engage in sporting activities. It was discovered that athletics, cultural events, literary activities, campaigns, and excursions are the most common extracurricular activities among undergraduate students.

Table 2

Role of co-curricular activities in leadership skills development 


\begin{tabular}{llllcc}
\hline \multicolumn{1}{c}{ Statements } & \multicolumn{1}{c}{ SA } & \multicolumn{1}{c}{ A } & \multicolumn{1}{c}{ DA } & \multicolumn{1}{c}{$\chi^{2}$} & \multicolumn{1}{c}{$\mathrm{P}$} \\
\hline $\begin{array}{l}\text { Co-curricular activities help achieve aims } \\
\text { in life }\end{array}$ & $28(46.7)$ & $27(45)$ & $05(8.3)$ & 16.90 & .000 \\
It develops decision-making power & $22(36.7)$ & $31(51.7)$ & $07(11.6)$ & 38.26 & .000 \\
It develops my self-confidence & $27(45)$ & $23(38.3)$ & $10(16.7)$ & 27.73 & .000 \\
It enhances communication skill. & $16(26.7)$ & $35(58.3)$ & $09(15)$ & 41.73 & .000 \\
It helps in making social interactions & $17(28.3)$ & $33(55)$ & $10(16.6)$ & 36.40 & .000 \\
It helps in establishing social relationships & $18(30)$ & $31(51.7)$ & $11(18.3)$ & 31.33 & .000 \\
Develops ability to meet challenges & $14(23.3)$ & $25(41.7)$ & $21(35)$ & 15.06 & .000 \\
$\quad$ effectively & & & & & \\
It develops team spirit & $18(30)$ & $29(48.3)$ & $13(21.7)$ & 24.93 & .000 \\
$\quad$ Develops spirit of sacrifice & $14(23.3)$ & $31(51.7)$ & $15(25)$ & 27.33 & .000 \\
Helps in understanding others' view points & $19(31.7)$ & $28(46.7)$ & $13(21.7)$ & 23.60 & .000 \\
Helps in becoming a team member & $24(40)$ & $27(45)$ & $09(15)$ & 29.73 & .000 \\
\hline
\end{tabular}

Table 2 shows the importance of co-curricular activities in the growth of leadership skills among undergraduates. 46.7 percent strongly believe, 45 percent agree, and 8.3 percent deny that participation in extracurricular sports aids them in meeting their life goals. Participation of cocurricular activities improves their decision-making ability, according to 36.7 percent of respondents who firmly approve, 51.7 percent agree, and 11.6 percent disagree. 45 percent of participants clearly believe, 38.3 percent agree, and 16.7 percent deny that participation in extracurricular activities improves their self-confidence. Participating in extracurricular activity improves students' communication abilities, according to 26.7 percent of students who firmly approve, 58.3 percent agree, and 15percent disagree.

Participating in extracurricular activity helps people engage socially, according to 28.3 percent of respondents who strongly approve, 55 percent who agree, and 16.6 percent who disagree. 30 percent of students firmly approve, 51.7 percent agree, and 18.3 percent deny that co-curricular experiences aid in the formation of social partnerships. 30 percent of participants strongly agree, 48.3 percent agree, and 21.7 percent disagree that participation in co-curricular activities develops their ability to meet challenges effectively; 23.3 percent of the respondents 
strongly agree, 41.7 percent agree, and 35 percent disagree that participation in co-curricular activities develops their team spirit; 23.3 percent of the respondents strongly agree, 41.7 percent agree, and 35 percent disagree that participation in co-curricular activities develops their ability to meet challenges effectively; 23.3 percent of the respondents strongly agree, 41.7 percent agree,

It emphasizes that participating in co-curricular activities builds students' leadership skills and is critical in the growth of leadership skills among graduates. Participation in co-curricular activities assists students in achieving their life goals, develop their decision-making power, enhance their self-confidence, establish social relationships, develop their ability to meet challenges effectively, develop team spirit, and develop the spirit of sacrifice and assisting them in understanding others' perspectives.

\section{Discussion}

The involvement of co-curricular activities in the creation of leadership skills among university students was the focus of the research. Sports, educational events, creative programs, campaigns, and excursions are the primary co-curricular activities in which students engage at university, according to the findings. Marsh and Kleitman (2002) described co-curricular activities as activities outside the classroom that include curriculum-related learning and character-building opportunities, supervised and/or funded by the school or college, and published similar results. Co-curricular programs are voluntary, do not have to be a component of the regular school or college schedule, do not include recognition, and are not evaluated. Cocurricular events are those things that are carried out inside or outside of the school or college grounds by joining multiple topic groups, societies, and student organisations that are sponsored by the Board of Education. Mani (2018) showed that co-curricular activities can take several 
types, including civic growth activities, voluntary service, recreational activities, physical development activities, cultural and aesthetic activities, literary and excursion activities. In a related way, Ahmad (2013) showed that Co-Curricular programs aim to complement the academic curriculum by providing opportunities for hands-on learning and instilling skills that help students improve their own abilities. Organizing various activities or projects exposes students to the modern environment, job ethic, and genuine problems in an indirect manner. This experiences will aid in the development of a healthy attitude while also improving soft skills.

In terms of the function of co-curricular activities in the development of leadership skills among university students, the study found that participating in co-curricular activities enhances students' leadership abilities and is critical for the development of leadership skills among graduates. Participation in co-curricular activities assists students in achieving their life goals, developing their decision-making power, enhancing their self-confidence, establishing social relationships, developing their ability to meet challenges effectively, developing team spirit, developing the spirit of sacrifice, and assisting them in understanding others' perspectives.

Co-curricular activities facilitate students in achieving their life goals, boosting their decision-making ability, strengthening their self-confidence, forming social bonds, increasing their capacity to overcome challenges effectively, cultivating team spirit, developing the spirit of commitment, and benefiting about others' perspectives. According to Ahmad (2013), CoCurricular events aim to complement the school curriculum by providing opportunities for handson learning and instilling skills that help students develop as individuals. Co-curricular programs, according to Yulk (2001), help students improve leadership skills. Caldwell and Smith (2005) highlighted the importance and importance of co-curricular experiences in a similar way. Educational programs have been classified as empowering young people to mix with adults and 
friends in order to set and achieve targets, productive competition, a lift from loss or rejection, and successful settlement of disputes. Co-curricular events improve students' teamwork, goal setting, organizing, communication, decision-making, dispute resolution, and group tolerance, according to a research by Klesse and D'Onofrio (2000). As a cognitive aspect, they learn from social experiences, self-esteem, self-confidence, and leadership abilities.

\section{Conclusion}

The study's first goal was to discover co-curricular events at the university level. The study discovered that the majority of university students partake in co-curricular activities, with athletics, cultural activities, literary activities, campaigns, and excursions being the most common. The study's second goal was to look at the connection between extracurricular activities and the growth of leadership skills in university students. According to the findings, participating in co-curricular activities improves students' leadership skills and plays an important role in the growth of leadership skills among graduates. Participation in co-curricular activities aids students in achieving their life goals, develops their decision-making power, self-confidence, improves communication skills, aids in social interactions, establishes social relationships, develops ability to meet challenges effectively, develops team spirit and the spirit of sacrifice, aids in understanding others' points of view, and aids in understanding others' perspectives. The study's third goal was to come up with techniques for coordinating extracurricular activities among university students.

The study emphasized the strategies of assigning equal importance to co-curricular activities, motivating students to participate in co-curricular activities, proper scheduling for arranging co-curricular activities, allocating sufficient financial resources for arranging cocurricular activities, providing proper equipment for arranging co-curricular activities, and 
provising sufficient financial resources for arranging co-curricular activities. Cocurricular activites have a great role in students achievements.

\section{Recommendations}

In view of the study's goals and conclusions, the researchers came up with the following suggestions. Provision of equal importance to co-curricular activities, motivation of students to participate in co-curricular activities, proper scheduling for arranging co-curricular activities, allocation of sufficient financial resources for arranging co-curricular activities, and provision of proper equipment are some of the most effective strategies for the development of co-curricular activities among university students. 


\section{References}

Ahmad, A. R., Adi, M. N. M., Noor, H. M., Rahman, A. G. A., \&Yushuang, T. (2013). The influence of leadership style on job satisfaction among nurses. Asian Social Science, 9(9), 172.

Allison, B. (1979). Student activities as the ultimate academic department. NASSP Bulletin, 63(426), 5-98.

Bassoppo-Moyo, S. (2007). The relationship between department chairs and academic program review.Academic Leadership Journal, 1(2), 18-23.

Caldwell, L. ., \& Smith, R. (2005). Participation in co-curricular activities. Journal of leisure research, 37(1), 51-76.

Darling et al., (2005). Participation in school-based extracurricular activities and adolescent adjustment. Journal of Leisure Research, 37(1): 51-76.

Dhanmeher, BR. (2014). Impact of Co-curricular Activities on the Non-Academic Development of Junior College Student. M. Phill Dissertation, DY Patil University, Navi Mumbai: PP20-21.

Klesse, E. J., \& D’Onofrio, J. A. (2000). The value of co-curricular activities: Co-curricular activities may not be tested or graded, but they educate-and benefit-students in ways that classroom activities cannot. Principal Leadership, 1(1), 5-8.

Kumar, et al., (2004) Status of Co-Curricular and Extra-Curricular Activi-ties in Primary Schools of Nepal: Problems and Prospects, Research Centre for Educational Inno-vation and Development Tribhuvan University Balkhu, Kathmandu, Nepal.

Kunjan, P. (2009). Handling Stress through Volleyball Game among Batu Pahat Vocational Scholl Student. 
Lupu, E. (2011). The leadership attitude-a way of preparing for life and the students' interest for sport activity. Procedia Social and Behavioral Sciences, 15, 1334-1339.

Mani, R. S. (2016). Factors Influencing Students' Participation in Co-Curricular Activities in Public Secondary Schools in Lamu County Kenya. Unpublished Master's Thesis, University of Nairobi.

Marsh, D., \& Kleithman, B. (2012). The extracurricular advantage. Educational Leadership, 86(1), 86- 87.

Sari et al., (2014). The role of perceived leadership behaviors as predictor of assertiveness levels in individual sport athletes. Procedia-Social and Behavioral Sciences, 152, 446-450.

Tucker, A. (1993). Chairing the academic department: Leadership among peers (3rd ed.) Phoenix: Oryz Press. Universities in Malaysia. ProQuestInfromation and LearningCompany.

Yulk, G. (2001). Leadership in Organization.PrenticeHall.Retrieved on30 October 2014 athttp://www.nscl.org.uk/media-F7B-97-randd-leadersbusiness-yukl.pdf.

Zaid et al., (2011). Penguasaankemahiranberpasukanmenerusipenyertaan di dalamKokurikulum: satutinjauan di Universiti Tun Hussein Onn Malaysia.Persidangan Pembangunan PelajarPeringkatKebangsaan.Universiti Teknologi Malaysia. 